\title{
EFFECT OF SOWING DATES ON GROWTH, YIELD ATTRIBUTES AND YIELD OF FOUR WHEAT VARIETIES
}

\author{
Ainullah Habibi ${ }^{1}$ \\ 1 Assistant Professor at Department of Agronomy, Agriculture Faculty of Baghlan University, \\ Pulikumri-3601Afghanistan \\ Tamim Fazily ${ }^{2}$ \\ ${ }^{2}$ Assistant Professor at Department of Agronomy, Agriculture Faculty of Baghlan University, \\ Pulikumri-3601Afghanistan
}

Article DOI: https://doi.org/10.36713/epra3895

\begin{abstract}
A field experiment entitled "Effect of sowing dates on growth, yield attributes and yield of four wheat varieties" was conducted during winter season of 2016-17 on sandy loam soils of Poz-e-Ishan Research Farm of Agricultural Faculty of Baghlan University. The experiment was laid out in split plot design viz. four dates of sowing comprised of (16 th November, 01' December, 16 ${ }^{\text {th }}$ December and 31 ${ }^{\text {st }}$ December 2016) as main plot treatments and four varieties (Solh 02, Gul 09, Muqawim 09, Kabul 013) as sub plot treatments with four replications. The highest plant height, number of effective per plant, test weight and grain yield of wheat was recorded with all varieties sown on 16 Nov-16, which was statistically identical with all treatments sown on 01 Dec-16 but significantly higher over rest of date of sowing. Among wheat varieties Kabul 013 and Gul 09 produced significantly higher plant height, number of effective per plant, test weight and grain yield of wheat over rest of the varieties.
\end{abstract}

KEY-WORDS: Date of sowing, wheat varieties, growth and yield

\section{INTRODUCTION}

Wheat (Triticum aestivum L.) being world first ranked grain crop is the mainstay of the agricultural economy and also known as 'King of cereals'. And also wheat is the second most important staple food crop of the world after rice. Wheat is the staple crop, accounting for about $83 \%$ of total cereal consumption in Afghanistan (Mail, 2010). A large part of the Afghan wheat crop is grown in the Northern provinces with the majority of the crop being dependent on seasonal precipitation. The 5-year average wheat grain yield production is 4.26 million tons. Harvested area is estimated at 2.55 million hectares (Geerts and Raes 2009, FAO 2002). Wheat, being a winter cereal, requires particular environmental conditions for better growth and yield (Dabre et al., 1993) and is more venerable if exposed to high temperatures during reproductive stages (Kalra et al., 2008). Too early sowing produces weak plants with poor root system, which leads to irregular germination, frequent death of the embryo and decomposition of endosperm due to activities of bacteria or fungi (Paul, 1992). While, late planting affects germination, growth, grain development (Haq \& Khan, 2002) and produces poor tillering due to winter injury in low temperature (Tahir et al., 2009).

Timely sowing of wheat provides optimum growing period for the crop growth which can accumulate more biomass and finally results in higher grain and biological yield. Therefore by keeping the above facts in consideration, this investigation was taken during winter season of 2016-17 to find out the effect of sowing dates on growth, yield attributes and yield of wheat. 


\section{OBJECTIVE}

To study the Effect of sowing dates on growth yield attributes and yield of four wheat varieties.

\section{METHODOLOGY}

The field experiment was conducted during winter season of 2016-17 on sandy loam soil with $\mathrm{pH}$ of 6.5 and organic matter $0.8 \%$ at Poz-e-Ishan Research Farm of Agricultural Faculty of Baghlan University in Afghanistan, to study effect of sowing dates on growth, yield attributes and yield of four wheat varieties. The experiment was laid out in split plot design viz. four dates of sowing comprised of $\left(16^{\text {th }}\right.$ November, $01^{\text {st }}$ December, $16^{\text {th }}$ December and $31^{\text {th }}$ December 2016) as main plot treatments and four varieties (Solh 02, Gul 09, Muqawim 09, Kabul 013) as sub plot treatments with four replications. All operations were performed as per crop recommendation. The row spacing was maintained $20 \mathrm{~cm} \times 10 \mathrm{~cm}$. The data on growth, yield attributes and yield of all varieties were recorded from different treatments.

\section{RESULTS AND DISCUSSION 4.1 Effect on growth}

The plant height of wheat was significantly higher with Kabul 013 and Gul 09 varieties over rest of the varieties. The date of sowing also affected the plant height of wheat; the plant height of wheat was higher with all varieties sown on 16-Nov-16 and were identical with all the varieties sown on 01-Dec-16 but significantly higher over the varieties sown in rest of date of sowing. These findings are in line with Madhu et al. (2018), who observed the highest plant height of wheat was measured with all the varieties sownon 15 November and the lowest plant height was found in 30 December. They also found significant differences among varieties in respect of plant height at harvest stages of the crop. Rout Satapathy (1994) observed higher plant height when wheat was sown on $21^{\text {st }}$ November and 1st December than the preceding and succeeding dates of sowing.

\subsection{Effect on yield}

The number of fertile tillers is dependent on seeding rate and environmental conditions during tiller development. Among the varieties Kabul 013 produced highest number of effective tillers per plant, which was identical with Gul 09 and but significantly higher over rest of the varieties. All the varieties which were sown on 16-Nov-16 produced higher number of effective tillers per plant, which was identical with all varieties sown on $01-D e c-16$, but significantly higher over rest of dates of sowing. This finding is with conformity with Rout Satapathy (1994) who recorded higher number of effective tillers when wheat was sown on 21st of November and 1st of December. Naik et al. (1991) reported that dates of sowing significantly influenced the plant height and yield attributes. The crop sown on 18th November produced significantly taller plants coupled with maximum number of effective tiller per plant.

Table 1: Effect of wheat date of sowing and varieties on plant height $(\mathrm{cm})$ at harvest

\begin{tabular}{|c|c|c|c|c|c|}
\hline \multirow[t]{2}{*}{ Date of sowing } & \multicolumn{4}{|c|}{ Varieties } & \multirow{2}{*}{ Mean } \\
\hline & Solh 02 & Gul 09 & Muqawim 09 & Kabul 013 & \\
\hline 16-Nov-16 & 95.87 & 96.67 & 93.60 & 98.97 & 96.28 \\
\hline 01-Dec-16 & 93.62 & 94.68 & 92.56 & 97.00 & 94.46 \\
\hline 16-Dec-16 & 85.80 & 89.61 & 86.78 & 90.28 & 88.12 \\
\hline 31-Dec-16 & 83.87 & 87.45 & 82.62 & 87.28 & 85.30 \\
\hline Mean B & 89.79 & 92.10 & 88.89 & 93.38 & \\
\hline \multicolumn{2}{|c|}{ Factors } & CD at $5 \%$ & & \multicolumn{2}{|c|}{ SEm \pm} \\
\hline \multicolumn{2}{|c|}{ Date of sowing } & 2.48 & & \multicolumn{2}{|c|}{0.76} \\
\hline \multicolumn{2}{|l|}{ Varieties } & 2.86 & & \multicolumn{2}{|c|}{0.99} \\
\hline \multicolumn{2}{|c|}{ Varieties at same level of date of sowing } & $\mathrm{N} / \mathrm{A}$ & & \multicolumn{2}{|c|}{1.53} \\
\hline \multicolumn{2}{|c|}{ Date of sowing at same level of varieties } & $\mathrm{N} / \mathrm{A}$ & & \multicolumn{2}{|c|}{1.88} \\
\hline
\end{tabular}

The highest test weight of wheat obtained with Kabul 013, where it was identical with Gul 09 but significantly higher over rest of the varieties. The date of sowing had also significant effect on test weight of wheat. All the varieties which were sown on 16-Nov-16 had higher but identical test weight with all varieties sown on 01-Dec-16, but significantly higher test weight over varieties sown in rest of dates. These finding are in line with Mukherjee (2012) who concluded that, sowing at November 15, significantly influenced the test weight and entire yield attributing character and was 
statistically at par with November 30 sowing, and significantly better to other dates of sowing.

The higher grain yield of wheat was obtained from Kabul 013 varieties, where it was statistically at with Gul 09 but significantly higher over rest of the varieties. Date of sowing had significant effect on grain yield of wheat. It was observed that all the varieties which were sown on 16-Nov-16 produced higher but identical grain yield with all the varieties sown on 01Dec-16, but significantly higher grain yield of wheat over rest of the varieties sown in rest of dates of sowing. With delay in each dates of sowing the grain yield of wheat was reduced.The significantly higher yield of wheat with varieties sown on16-Nov-16 and
01-Dec-16 wheat can be justified owing to favourable temperature requirement as per crop need boosting crop growth in the form of higher photosynthate accumulation and resulting higher yield parameters and final yield of wheat crop. These findings are in compare with Behera (1994), who reported that higher temperature during later part of the crop growth in delayed sowing caused forced maturity of the crop and resulted in lower test weight, less filled grains and ultimately the lower grain yield. Kumar et al. (1994) obtained highest mean yield with early sown wheat whereas, poorer grain and straw yield were obtained from the late sown wheat.

Table 2: Effect of wheat date of sowing and varieties on number of effective tillers per plant at harvest

\begin{tabular}{|c|c|c|c|c|c|}
\hline \multirow{2}{*}{ Date of sowing } & \multicolumn{4}{|c|}{ Varieties } & \multirow[b]{2}{*}{ Mean } \\
\hline & Soh 02 & Gul 09 & Muqawim 09 & Kabul 013 & \\
\hline 16-Nov-16 & 4.00 & 4.25 & 3.50 & 4.50 & 4.06 \\
\hline 01-Dec-16 & 3.75 & 4.00 & 3.25 & 4.25 & 3.81 \\
\hline 16-Dec-16 & 3.00 & 3.50 & 2.75 & 3.50 & 3.19 \\
\hline 31-Dec-16 & 2.75 & 3.25 & 2.75 & 3.25 & 3.00 \\
\hline Mean B & 3.38 & 3.75 & 3.06 & 3.88 & \\
\hline \multicolumn{2}{|l|}{ Factors } & CD at $5 \%$ & & \multicolumn{2}{|l|}{ SEm \pm} \\
\hline \multicolumn{2}{|l|}{ Date of sowing } & 0.45 & & \multicolumn{2}{|l|}{0.14} \\
\hline \multicolumn{2}{|l|}{ Varieties } & 0.46 & & \multicolumn{2}{|l|}{0.16} \\
\hline \multicolumn{2}{|c|}{ Varieties at same level of date of sowing } & $\mathrm{N} / \mathrm{A}$ & & \multicolumn{2}{|l|}{0.28} \\
\hline \multicolumn{2}{|c|}{ Date of sowing at same level of varieties } & $\mathrm{N} / \mathrm{A}$ & & \multicolumn{2}{|l|}{0.31} \\
\hline
\end{tabular}

Table 3: Effect of wheat date of sowing and varieties test weight (g)

\begin{tabular}{|c|c|c|c|c|c|}
\hline \multirow[b]{2}{*}{ Date of sowing } & \multicolumn{4}{|c|}{ Varieties } & \multirow[b]{2}{*}{ Mean } \\
\hline & Solh 02 & Gul 09 & Muqawim 09 & Kabul 013 & \\
\hline 16-Nov-16 & 35.85 & 37.31 & 35.29 & 36.69 & 36.28 \\
\hline 01-Dec-16 & 35.66 & 36.83 & 33.61 & 36.86 & 35.74 \\
\hline 16-Dec-16 & 34.83 & 35.65 & 33.46 & 36.90 & 35.21 \\
\hline 31-Dec-16 & 32.95 & 33.59 & 32.20 & 34.74 & 33.37 \\
\hline Mean B & 34.82 & 35.84 & 33.64 & 36.30 & \\
\hline \multicolumn{2}{|l|}{ Factors } & \multicolumn{2}{|c|}{ CD at $5 \%$} & \multicolumn{2}{|c|}{ SEm \pm} \\
\hline \multicolumn{2}{|l|}{ Date of sowing } & \multicolumn{2}{|c|}{1.02} & \multicolumn{2}{|c|}{0.32} \\
\hline \multicolumn{2}{|l|}{ Varieties } & \multicolumn{2}{|l|}{0.74} & \multicolumn{2}{|c|}{0.26} \\
\hline \multicolumn{2}{|c|}{ Varieties at same level of date 0f sowing } & \multicolumn{2}{|l|}{$\mathrm{N} / \mathrm{A}$} & \multicolumn{2}{|c|}{0.63} \\
\hline \multicolumn{2}{|c|}{ Date of sowing at same level of varieties } & $\mathrm{N} / \mathrm{A}$ & & \multicolumn{2}{|c|}{0.55} \\
\hline
\end{tabular}


Table 4: Effect of wheat date of sowing and varieties on grain yield (kg/ha)

\begin{tabular}{|c|c|c|c|c|c|}
\hline \multirow[b]{2}{*}{ Date of sowing } & \multicolumn{4}{|c|}{ Varieties } & \multirow[b]{2}{*}{ Mean } \\
\hline & Solh 02 & Gul 09 & Muqawim 09 & Kabul 013 & \\
\hline 16-Nov-16 & 4906 & 5328 & 4682 & 5783 & 5175 \\
\hline 01-Dec-16 & 4762 & 4894 & 4547 & 5142 & 4836 \\
\hline 16-Dec-16 & 4241 & 4399 & 3958 & 4521 & 4280 \\
\hline 31-Dec-16 & 4059 & 4193 & 3971 & 4302 & 4131 \\
\hline Mean B & 4492 & 4703 & 4289 & 4937 & \\
\hline \multicolumn{2}{|l|}{ Factors } & \multicolumn{2}{|l|}{ CD at $5 \%$} & \multicolumn{2}{|c|}{ SEm \pm} \\
\hline \multicolumn{2}{|l|}{ Date of sowing } & \multicolumn{2}{|l|}{401} & \multicolumn{2}{|c|}{124} \\
\hline \multicolumn{2}{|l|}{ Varieties } & \multicolumn{2}{|l|}{364} & \multicolumn{2}{|c|}{126} \\
\hline \multicolumn{2}{|c|}{ Varieties at same level of date of sowing } & \multicolumn{2}{|l|}{$\mathrm{N} / \mathrm{A}$} & \multicolumn{2}{|c|}{247} \\
\hline \multicolumn{2}{|c|}{ Date of sowing at same level of varieties } & \multicolumn{2}{|l|}{$\mathrm{N} / \mathrm{A}$} & \multicolumn{2}{|c|}{252} \\
\hline
\end{tabular}

\section{CONCLUSION}

To obtain the higher yield of wheat crop under situation of Baghlan province, Afghanistan. The optimum date of sowing for wheat varieties of Solh 02 , Gul 09, Muqawim 09, Kabul 013 found to be 16-Nov-16, however 01-Dec-16 is also suitable. Among the varieties Kabul 013 had higher but identical growth, yield attributes and yield of wheat with Gul 09 but significantly higher over rest of the varieties.

\section{Recommendations}

To obtain the higher yield of wheat crop under situation of Baghlan province, Afghanistan. Kabul 013 is recommended to be sown on 16-Nov-16.

\section{REFERENCES}

1. Behera, Ashwani Kumar (1994). Response of wheat (Triticum aestivum) varieties to sowing date. Indian J. Agron. 39(1): 171-173.

2. Dabre, W.M., S.B. Lall and G.L. Lngole. 1993. Effects of sowing dates on yield, ear number, stomatal frequency and stomatal index in wheat. $J$. Maharashatra Agric. Univ., 18: 64-66.

3. FAO (2002) .Deficit water irrigation practice. Water Reports 22. Rome, Italy: Food and Agriculture Organization of the United Nations.

4. Geerts S, Raes D.2009. Deficit irrigation as onfarm strategy to maximize crop water productivity in dry areas. Agricultural water management, 96 (9):1275-1284.

5. Haq, N.U. and M. Khan. 2002. Effect of planting date, chlortoluran + MCPA and wheat varieties on weed control and wheat yield. Sarhad J. Agric., 18(2): 443-447.

6. Kalra, N., D. Chakraborty, A. Sharma, H.K. Rai, M. Jolly, S. Chander, P.R. Kumar, S. Bhadraray,
D. Barman, R.B. Mittal, M. Lal and M. Sehgal. 2008. Effect of increasing temperature on yield of some winter crops in northwest India. Current Sci., 94(1): 82-88.

7. Kumar, R., Medan, S. and Yunus, H. (1994). Effect of planting dates on yield and quality in durum varieties of wheat. Haryana Agric. Univ. J. Res. 24: 186-188.

8. Mukherjee, D. 2012. Effect of sowing dates on growth and yield of wheat (Triticumaestivum) cultivars under mid hill situation of West Bengal. Indian Journal of Agronomy 57(2): 152-156.

9. Naik, P.L., Patel, Boa and Kalaria, K.K. (1991). Response of wheat (Triticum aestivum) varieties to sowing date and seed rate. Indian J. Agron. 36: 225-226 (Suppl.).

10. Paul, S.R. (1992). Effects of pre-sowing treatments, seed rates, fertility levels and surface soil competition on growth and yield at late sown rain-fed wheat in Assam. Agric. Res., 13:410-411.

11. Rout, D. and Satapathy, M.R. 1994. Effect of date of sowing on wheat varieties in Umerkote Zone of Orissa. Indian Journal of Agronomy 32(3): 466468.

12. Tahir, M., A. Ali, M.A. Nadeem, A. Hussain and F. Khalid. 2009. Effect of different sowing dates on growth and yield of wheat (Triticum aestivum L.) varieties in district Jhang, Pakistan. Pak. J. Life Soc. Sci., 7(1): 66-69.

13. Utpal Madhu, Mahfuza Begum, Abdus Salam and Shubroto Kumar Sarkar. 2018. Influence of sowing date on the growth and yield performance of wheat (Triticum aestivum L.) varieties. Arch. Agr. Environ. Sci., 3(1): 89-94 